UDC 346.544.42:340.5:339.9.012.23

JEL Classification: F13, L15, 019

http://doi.org/10.21272/mmi.2019.1-26

Bogdan V. Derevyanko,

D.Sc., Professor, Donetsk Law Institute of the Ministry of Internal Affairs of Ukraine, Ukraine

Oleh M. Rieznik,

Ph.D., Associate Professor, Sumy State University, Ukraine

Tetiana V. Shlapko,

Ph.D., Associate Professor, Sumy State University, Ukraine

Tetyana G. Popovych,

National Academy of Law Sciences of Ukraine, Ukraine

\title{
FUNDAMENTALS OF A NATIONAL STANDARDIZATION SYSTEM AS A MEANS CONFIRMING THE QUALITY AND INNOVATION OF PRODUCTS: EXPERIENCE OF INTERNATIONAL ORGANIZATIONS IN UKRAINE AND CANADA
}

\begin{abstract}
The article deals with the analysis of requirements of the International Organization for Standardization, other intergovemmental organizations and Canada's national requirements for standardization as a means of confirming the quality and innovation of products. The analysis revealed the peculiarities and regularities in the legal regulation of standardization at the international level. Considerable attention was paid to the analysis of the economic and legal provision of standardization in Canada, where the high-quality application of modern rules of standardization by business entities significantly increased the quality of products at the microeconomic level and the main macroeconomic indicators at the state level through the introduction of innovations as standards. The GDP of other economically developed countries increased due to the application of modern standards. The analysis carried out using comparative studies, statistical and economic comparison and modelling provided an opportunity to formulate the basic principles of developing a national standardization system in Ukraine. They include voluntariness and freedom of standardization; support and updating of legislation; balancing between the requirements that determine the essential requirements for human health, environmental safety and product quality, and self-regulation for the business entity; utility and efficiency of standards in determining responsibility; assisting a consumer or other interested person to determine whether the product is faultless; provision of the right of parties to the contractor an end-user to eliminate the malfunction, delivery of a faultless product or compensation for any losses incurred due to lack of guaranteed characteristics; popularization of the standardization for economic entities.

Keywords: standardization, innovation, International Organization for Standardization, Canada, quality, business entity, efficiency.
\end{abstract}

Introduction. Any product, regardless of its purpose, developed in all, without exception, industries in the vast majority of countries worldwide must comply with national and international standards. Such compliance confirms the quality and innovation of products. The compliance itself is confirmed by specialized international and national organizations. The International Organization for Standardization (hereafter referred to as ISO) is a collegial body that unites 163 countries. Standards affect about $80 \%$ of the world trade of commodities, most of which are products of innovation. Those countries that are not full and active members of the ISO allow others to decide how to set standards and conditions for international trade. The ISO membership includes the rights and benefits that should be actively used, the good practices and responsibilities should be followed, as well as the improvement of the ISO system and the provision of proposals to global ISO customers (ISO membership manual, 1946, pp. 5-6). In addition to ISO, a large number of international and national organizations and bodies observe compliance with standards on products. Ukraine has its own standardization system, which was inherited from the former USSR. The launch of products manufactured by Ukrainian business entities on international markets requires confirmation of their quality and innovation based on the use of fundamentally new principles for building a national standardization system in Ukraine based on the analysis of international and national

Cite as: Derevyanko, B. V., Rieznik, O. M., Shlapko, T. V., \& Popovych, T. G. (2019). Fundamentals of a National Standardization System as a Means Confirming the Quality and Innovation of Products: Experience of International Organizations in Ukraine and Canada. Marketing and Management of Innovations, 1, 314324. http://doi.org/10.21272/mmi.2019.1-26 
B. V. Derevyanko, O. M. Rieznik, T. V. Shlapko, T. G. Popovych. Fundamentals of a National Standardization System as a Means Confirming the Quality and Innovation of Products: Experience of International Organizations in Ukraine and Canada

requirements of economically developed countries for standardization as a means of confirming the quality and innovation of products.

Literature Review. Heires states that international standards are a lubricant for global trade. They govern the interplay of things like screw threads, smart cards or freight containers, thereby reducing the costs and hassles of incompatible or unfitting products from different origins. Among the burgeoning number of transnational standard setters, the ISO represents one of the oldest and most active organisations (Heires, 2008, p. 357).

Louis and Ruwet state that representativeness has become a keyword in reform projects of global governance. While it often appears as a cure for the legitimacy deficit of international organizations, this notion has hardly been defined at the global level. This article aims at filling this void by providing a sociohistorical account of the meanings and uses of this concept based on a comparison of the International Labor Organization (ILO) and the International Organization for Standardization (ISO), two of the oldest organizations in the global arena (Louis and Ruwet, 2017).

Professor Prasad from India examines the impact of standardization on the activities of medical actors. He points out that ISO standards address social and all its activities as a whole. They play an important role in the stabilization and growth of national and international interactions. ISO Standards have a unique value. His paper takes a comprehensive view of ISO and its activities, and also as to how dental institutions can gain by implementing the ISO process in its activities, bringing about standardization in practices and education (Prasad, 2013).

Kasperaviciute's article provides an analysis of experiences of higher education institutions in implementing the ISO 9001 standard. Reasons for the implementation of the standard, the most common issues co-occurring during the implementation process as well as the benefits of a standardised quality management system are identified and analysed in the article (Kasperaviciute, 2012).

A group of Italian researchers suggested the project for standardization of rehabilitation programmes in different countries in Europe (Tennant, Grimsby, Marincek, Phillips, Ring, Biering-Sorensen, ... Thonnard, 1999).

Zoga's and Pano's paper verifies that all companies do report benefits from the certification, although they are of variable types. The paper concludes with some suggestions about measuring of certification' effects on the performance of companies, as well as revealing of factors that can contribute to higher profitability of Albanian companies during the implementation of ISO 9000 normative. The authors intend to bring a modest contribution and encourage further studies on the field, closely related to the characteristics of Albanian businesses (Zoga and Pano, 2016).

Hanaba is looking for ways to improve the Ukrainian education system. In her work, standardization is considered rather as a negative factor, which is counterweighted by innovation in education. The author believes that productive in this perspective is the idea of the British researcher and teacher Ken Robinson. The purpose of education is seen the essence of ability to help those who are learning to understand the environment and identify internal talents in order to realize themselves as a personality. Human will be able to perform their individual purpose as a personality, cultural purpose, economic purpose (Hanaba, 2017).

Husser et al. in their chapter provide a bottom-up perspective on bioinformatics data standards, beginning with a historical perspective on biochemical nomenclature standards (Husser C.S. et al., 2006).

Corvett and Kirsch in their work on the ISO 14000 standard indicate that the fact that ISO 9000 appears as an important factor explaining the diffusion of ISO 14000 certifications suggests that the drivers behind the two have significant overlap. This indicates that, although ISO 14000 is an environmental standard, many of the factors driving national certification patterns are not at all environmental in nature, and that 
B. V. Derevyanko, O. M. Rieznik, T. V. Shlapko, T. G. Popovych. Fundamentals of a National Standardization System as a Means Confirming the Quality and Innovation of Products: Experience of International Organizations in Ukraine and Canada

ISO 14000 , therefore, needs to be studied from a broader perspective than from a purely environmental point of view (Corvett and Kirsch, 2001).

German professors Blind, Jungmittag and Mangelsdorf conducted a new empirical study by the example of various states and regions, in which they investigated and presented schematically the interrelationships between standardization and gaining additional profits by states (Blind, Jungmittag and Mangelsdorf, 2011). The results of the study are important and interesting, but the study was conducted 8 years ago.

As can be seen, the analysis of the economic and legal provision of standardization in various fields and areas of economy and the social sphere was carried out by scientists from different countries at different times. They investigated various social relations concerning the development and implementation of standards to confirm the quality and innovation of products manufactured in different countries. However, the vast majority of studies are conducted within completely different fields of science and the study of individual elements of standardization is carried out to achieve the specific objective of a particular branch of science. In addition, the analysis is often carried out by an example of legislation and economic practices of countries that cannot be recognized as an example of economically developed countries, or because of other reasons, the peculiarities of standardization in these countries cannot be relevant for the application of an innovation strategy in the formation of standardization in Ukraine. The experience of Canada as a state, which standardization system was originally formed in England as a metropolis and later changed to fulfil local needs, is the most similar one and can be used. Similarly, the system of standardization of Ukraine was originally formed in Moscow, and it changed to local needs in the last two decades. The climate of the major part of Canada's territory is similar to that of Ukraine; the attitude to the means of production (including land), labour, consumers and counteragents, the quality of products of the inhabitants of Canada is similar to the attitude of Ukrainian citizens; in general, the mentality of a large part of the Canadians is similar to the mentality of Ukrainians. Therefore, Canada's provisions on standardization are relevant if necessary to improve similar provisions in Ukraine. Similarly, scientists need to analyze the situation regarding the activities of international organizations on standardization, since Ukraine is their actual or potential member.

The purpose of this article is to analyze the requirements of international standardization organizations and Canadian national standards for standardization as a means of confirming the quality and innovation of products, based on which the principles of building a system of national standardization in Ukraine are formulated.

Results. ISO and its members are bound by legal obligations in matters of competition or antimonopoly offences, protection of personal data and copyright. It should be noted that some ISO standards might be subject to patent rights. Currently, the ISO development strategy is formed by tasks that involve the creation of standards and their dissemination, and the implementation of social, security and educational goals that should facilitate international trade. In parallel with ISO, regional and national standardization organizations that work with the global organization operate, but form the basic requirements for their region, taking into account national traditions, established rules and other social principles of society in a particular union. They include the Inter-Nordic Cooperation on Standardization, the EuroAsian Interstate Council for Standardization, Metrology and Certification, the Pan American Standards Commission, the ASEAN Consultative Committee on Standards and Quality, Pacific Area Standards Congress, the Arab Organization for Industrial Development and Mining, African Organisation for Standardisation. The first two organizations operate within Europe, but today the CEN, which forms the standardization policy of Europe, comes first.

The CEN is recognized by the EU as a European standardization organization. The legal basis for its work is Regulation (EU) No 1025/2012 of the European Parliament and of the Council of 25 October 2012 on European standardization (2012). Just like ISO, CEN combines knowledge and expertise from its 
B. V. Derevyanko, O. M. Rieznik, T. V. Shlapko, T. G. Popovych. Fundamentals of a National Standardization System as a Means Confirming the Quality and Innovation of Products: Experience of International Organizations in Ukraine and Canada

members, business and industry, as well as other stakeholders to develop EN for products, materials, services and processes that embrace the latest technology.

The standardization system in Europe is based on the national standardization bodies of the CEN members. The national standardization body is the only information centre for all stakeholders and is the main access point to a coherent system that includes regional (European) and international standardization. National CEN members are responsible for implementing EN as national standards. The national standards bodies distribute and sell the implemented EN and should remove any conflicting national standards. CEN, in turn, works with its members to develop and define EN in response to specific needs or innovations that companies and other users have identified as standards.

As noted, every national standardization body that is part of the CEN system is required to accept each EN as a national standard and make it accessible to clients in their country. Thus, one EN becomes the national standard in all 34 countries of the CEN.

The result of work in the technical committees of CEN is the creation of an EN based on consensus. It is important to note that the use of standards is voluntary, and therefore there is no legal obligation to apply them. About $30 \%$ of ENs, published by CEN, was developed in response to specific requests (mandates for standardization) issued by the European Commission. Many of these standards are known as «harmonized standards». They provide an opportunity for businesses to ensure that their products or services comply with the essential requirements enshrined in European law (EU Directive). In such cases, we can say that the standard provides for a «presumption of conformity» with the basic requirements of the law. At the same time, they stimulate the enterprise to aspire a new level of innovation development.

European standardization is a key tool for consolidating the single market and facilitating cross-border trade within Europe and in world markets. It is a valuable tool for increasing the competitiveness of European companies, which creates conditions for the economic growth of business entities.

The countries of the former socialist camp, which are still far from moving away from the standardization used in the USSR, as well as Ukraine, necessarily define the unification, interchangeability and compatibility as the principles. At the same time, the countries that were originally based on international standards in the sphere of standardization put the modern aspects of standardization-trade, elimination of technical barriers and security-in the first place among the principles.

The principle of voluntary application of standards applies in all countries as set out in international standards. Thus, all requirements not covered by the law are voluntary. France, Germany, Italy regard voluntariness as one of the basic principles of standardization. The position of Austria, Belgium, the Federal Republic of Germany, Portugal and Macedonia is quite interesting, as the requirements explicitly envisaged in the contract (agreement) are also mandatory. They are equated with legislative requirements and provided with the same measures for their implementation.

The main stakeholders are business entities since standardization is never an end in itself, it is the basis for the value-added chain, optimization and efficient use of resources. Participation in standardization provides these entities with advantages:

1. Getting first-hand knowledge about upcoming events and trends in innovation. It gives the company a competitive temporal advantage in globalized markets.

2. Impact on the development of standards, which provides an opportunity to protect their investments in products, research and development. Stakeholders can draw attention to environmental protection or consumer issues.

3. Building a network of standardization committees (organizations, groups) is an ideal place to meet and establish new contacts for the exchange of ideas and technology and innovation enhancements.

4. Developing and sharing knowledge. Participants in the committees (organizations, groups) of standardization are highly specialized experts who will provide first-hand information. 
B. V. Derevyanko, O. M. Rieznik, T. V. Shlapko, T. G. Popovych. Fundamentals of a National Standardization System as a Means Confirming the Quality and Innovation of Products: Experience of International Organizations in Ukraine and Canada

As a result, it can be noted that European countries allow and help national economic entities to use standardization as an effective strategic tool. For example, standards are used at an early stage of development to prepare the market for an innovative product, and then standardization helps to shape the market, increases the security of investments, and supports deregulation. Standardization helps alleviate the legislative burden on the state when legislators can focus on general security issues, referring to standards for technical details. On the other hand, as a tool for deregulation, standards are beneficial to the private sector and consumers by protecting them from excessively rigid laws, while simultaneously releasing the state from responsibility for drawing up detailed technical requirements and introducing innovations. In some countries, the national standardization body is a non-governmental public organization that performs its functions effectively, receiving a vote of confidence from the public and private law entities, providing an opportunity to balance the tools of imperative and discretionary regulation of standardization relations. In Europe, such countries include Hungary, Denmark, Iceland, Ireland, Norway, Poland, Spain, Sweden, Switzerland, and the United Kingdom.

As a rational way to ensure compliance with the rules, standards stimulate trade in domestic and foreign markets. Voluntary standards are one of the forms of flexible self-regulation for business entities and make it possible to eliminate the need for state regulation tools that tend to be more rigid and less flexible. Standardization of most products and services in European countries is a voluntary process, but some requirements are established by law through European directives and national legislation. In particular: mandatory safety standards; the standards specified in regulatory legal acts; food hygiene standards. National laws of European countries provide a legal framework and set goals for protection and security, while standards based on consensus describe ways to achieve these goals in detail.

The economic benefits of standardization make up about $1-1.5 \%$ of the gross domestic product. Such results were obtained from surveys in Germany, Austria, Switzerland, Italy by the standardization associations (DIN, ON, SNV and UNI respectively) (La normazione? Aiuta an increment are il PIL, 2014). Ukraine should evaluate these results and take into account that standardization creates significant value for the national economy.

Next, we suggest focusing on Canadian experience in introducing innovations into standards. Over 150 years of the existence of the Confederation of Canada, there has been a significant path from streamlining industrial works to globalization processes, including eliminating barriers to trade. By 1917, Canada used standardization and requirements developed by the United Kingdom (according to the protectorate), but it happened that it was the United Kingdom that invited Canada to establish its first standards committee to address the problems of «Canadian origin»: the vastness of the territory, the diversity of industrial production, extreme weather conditions, etc. The Canadian Technical Standards Committee consisted of volunteers who promised to put in place an order in industrial work, developing standards on a consensus basis, while coordinating with colleagues from the United Kingdom, the United States and other Allies. In 1919, the group received a statute from the federal government for the creation of CESA. Thus, this organization was created as an association of business, which worked as a non-profit organization, but served as a state body for standardization.

Without waste of time, CESA released its first standard for innovative steel rail bridges in 1920, due to several tragic cases when replacing wooden constructions on metal. Innovation leads to standards aimed at improving public health in Canada through milk pasteurization, sewage treatment and water treatment. In the early days of the emergence of electricity, CESA has published a collection of electrical standards called the Canadian Electric Code (1927). Until the Second World War, quality management systems and standards for the manufacture of mechanical parts, communication facilities, weapons and engines gradually became important, due to the emergence of new technologies that were supported by international standards. Today, the priority is the promotion of higher education in the field of standardization and sustainable tourism. In 2010, Vancouver hosted the Winter Olympics, and a 
B. V. Derevyanko, O. M. Rieznik, T. V. Shlapko, T. G. Popovych. Fundamentals of a National Standardization System as a Means Confirming the Quality and Innovation of Products: Experience of International Organizations in Ukraine and Canada

combination of innovation and standardization has been a key to success and honesty in Canada since the Canadian Council of Standards helped secure a fair match by accrediting the International Anti-Doping Laboratory of the Olympics under the International Standard for Testing and Calibration (ISO/IEC 17025: 2005). The standardization has a strategic value when special attention is paid to the role of standards in the spheres of social and economic development.

Canada was the first in the world to release the then-current standard on employees' mental health as, according to the Mental Health Commission of Canada (MHCC), mental illness in Canada resulted in up to 35 million loss-making days each year costing Canadian enterprises 198 billion Canadian dollars (30 years) (Annual Report, 2015). Keeping employees mentally healthy has both a social and economic sense. That is why the MHCC has been leading the standardization work in this area and has introduced the new CAN/CSA-Z1003-13/BNQ 9700-803/2013 «Psychological health and safety in the workplace Prevention, promotion, and guidance to staged implementation.». For employers, this standard should be the starting point for creating policies, curricula and audits that make mental health a top priority when providing a social package in the workplace. This standard also helps employers to identify the danger to the employee's welfare, for example, stress from too many requirements. It also recommends that employees receive respect from management and be rewarded for their good work. The standard CAN/CSA-Z1003-13/ is free of charge when downloaded from the CSA Group website (it is necessary to provide identification data), which makes it available to companies of different sizes. This national standard has been downloaded more than 16,000 times during the first year, indicating that Canadians are keenly interested in having a robust mechanism for solving mental health risk at the workplace. (CAN/CSAZ1003-13/BNQ 9700-803/2013). In Canada, standards are often developed by a non-governmental organization (in this case, CSA Group), but the standard becomes national (designated as «CAN/»). The standard is voluntary, but its application is a matter of honour for Canadian companies, which provides them with benefits both for employees and for counterparties and end users.

The value of standardization for the economy of Canada:

During the 1990s, the trends of globalization, environmental friendliness and multilateralism forced countries worldwide to determine their place in the global economy. The creation of the WTO in 1995 emphasized the need for this task and inspired many countries to abandon national standards and adopt international standards that foster free trade and economic development. The interests of Canada as a country with an export-oriented economy were part of these international movements. It was important to participate in the development of international standards in key areas to make sure they meet the needs of Canada. To effectively participate in international standardization, Canada has set up a plan that encourages the participation of all stakeholders in the Canadian states to manage their standardization processes in these new global circumstances.

The Canadian Standards Strategy, published in 2000, was one of the world's first innovation strategies for national standards. Key industrial countries, including China, France, Germany, Japan and the United States, continue to develop their own standards strategies based on the principles developed and applied in Canada. They are in particular:

1. Creation and understanding of the structure of standardization actors taking into account the interests of stakeholders, which included representatives of industry, government, non-governmental organizations, organizations for the development of standards, conformity assessment bodies and other persons.

2. increasing the presence (profiling) of Canada internationally, in particular in the ISO and the IEC.

3. Raising awareness of how standards can affect Canada's economy.

4. Determining the priority of their (national) standards in certain sectors of the economy. 
B. V. Derevyanko, O. M. Rieznik, T. V. Shlapko, T. G. Popovych. Fundamentals of a National Standardization System as a Means Confirming the Quality and Innovation of Products: Experience of International Organizations in Ukraine and Canada

Standards serve as standardization tools and tools to help provide better, safer and more efficient methods for producing goods and services, and are important elements of technology, innovation and trade.

Activities in the development of standards are inextricably linked with the support of sustainable development of society, public health, state security, social security of workers and consumer protection. Canada is particularly active in attracting new or emerging economies to standardization activities. Often interested parties (business entities in a particular industry) have no information about the opportunities that arise when carrying out work on standardization and conformity assessment. Improving the knowledge of these sectors about standardization will help them to participate in developing new standards that will further influence their role and participation in market relations. A central coordinating role in such processes in Canada is played by the Standards Board, which collects information on standardization needs in innovative industries and explores ways of establishing contacts and working arrangements between actors.

The process of developing standards in Canada is specialized in the profile of the relevant industrial sectors. The Canadian National Standardization System satisfies this approach, which provides the opportunity to stimulate the introduction of relevant proposals from business entities in individual industries. At the same time, it provides an opportunity to rely on intellectual and financial support from these entities.

The foregoing demonstrates that Canada defines technical and technological progress, the development of technologies and innovations as the basis of modern standardization. Standardization in Canada statically establishes the requirements for objects and implies the dynamics-the introduction, use, assessment of compliance with the requirements of standards used. Participation in standardization involves a wide range of people, including consumers. Standardization also helps businesses and balances the interests of stakeholders to liberalize trade, solve common social problems and protect consumers' rights. Ukraine should take such initiatives.

A confirmation of the above is the quantification of the standardization indicators in Ukraine and Canada (Figures 1 and 2). The research object is the ISO 9001 standard-the most widely used standard of business process quality worldwide, which defines the level of management organization by business entities. Thus, by analyzing the indicators of the ISO 9001 standard in Ukraine and Canada for 2007-2017, we note that during the period under study the volume of received ISO 9001 standards by the business entities of Canada was, on average, by 5,605 units more than in Ukraine. Moreover, it is fair to say that the rate of reduction of this standard in Canada for ten years was $20.3 \%$, and it was almost $40 \%$ in Ukraine. This testifies both to the significantly lower level of standardization by Ukrainian enterprises as compared to Canadian business entities and the negative tendency of a significant reduction of the standardization process in Ukraine in the period from 2011-2017.

By examining the affiliation of enterprises, which have received the ISO 9001 standard, to a specific branch of the economy (Figure 2), we note that only food and tobacco companies in Ukraine have received more standards than Canadian enterprises. In turn, it is fair to note that this trend is due to the monopolization of the food market in Canada by transnational companies, whereas a significant number of enterprises is operating in this sector in Ukraine. In all other sectors of the economy, the number of Canadian companies that have received the ISO 9001 standard is significantly greater the Ukrainian enterprises, which indicates, respectively, the greater innovation and quality of products manufactured in Canada. Thus, standardization was carried out by Canadian companies in the following sectors of the economy (by more than 200 units as compared to Ukrainian enterprises): rubber and plastic products, metal and fabricated metal products, machinery and equipment, electrical and optical equipment, construction, wholesale and retail trade, repairs of motor vehicles, motorcycles. This situation shows a 
B. V. Derevyanko, O. M. Rieznik, T. V. Shlapko, T. G. Popovych. Fundamentals of a National Standardization System as a Means Confirming the Quality and Innovation of Products: Experience of International Organizations in Ukraine and Canada

significant lag of high-tech industry enterprises of Ukraine from enterprises of Canada, as the level of standardization in the corresponding branches of the economy is less than five times on average.

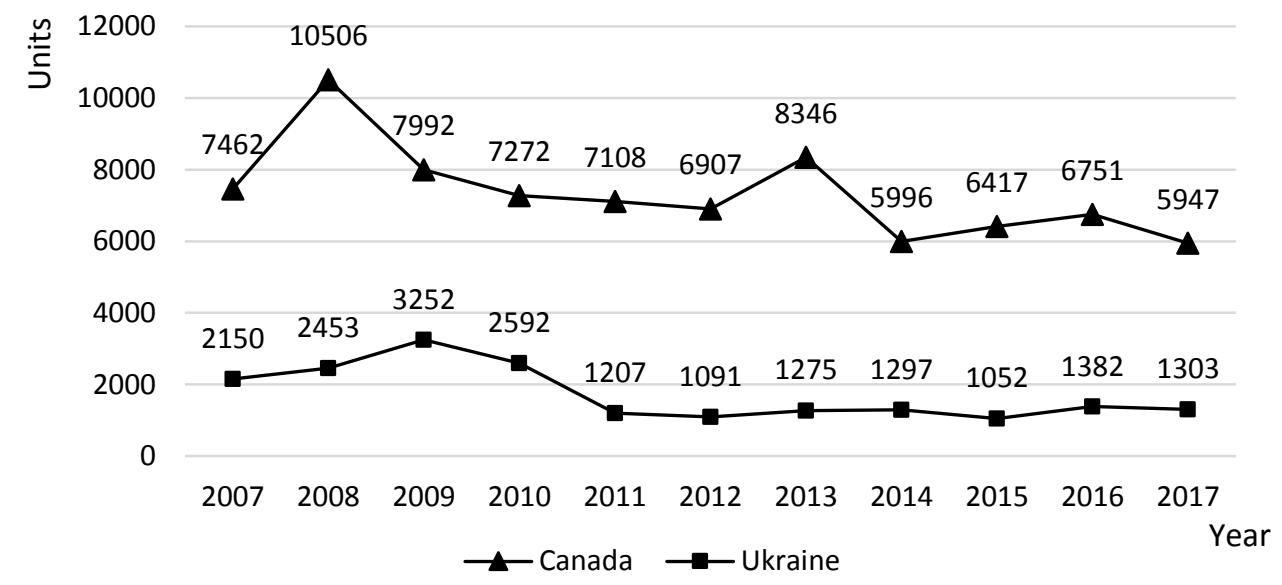

Figure 1. Dynamics of the quantity of ISO 9001 standards in Canada and Ukraine for 2007-2017 Source: compiled based on the data of the International Organization for Standardization.

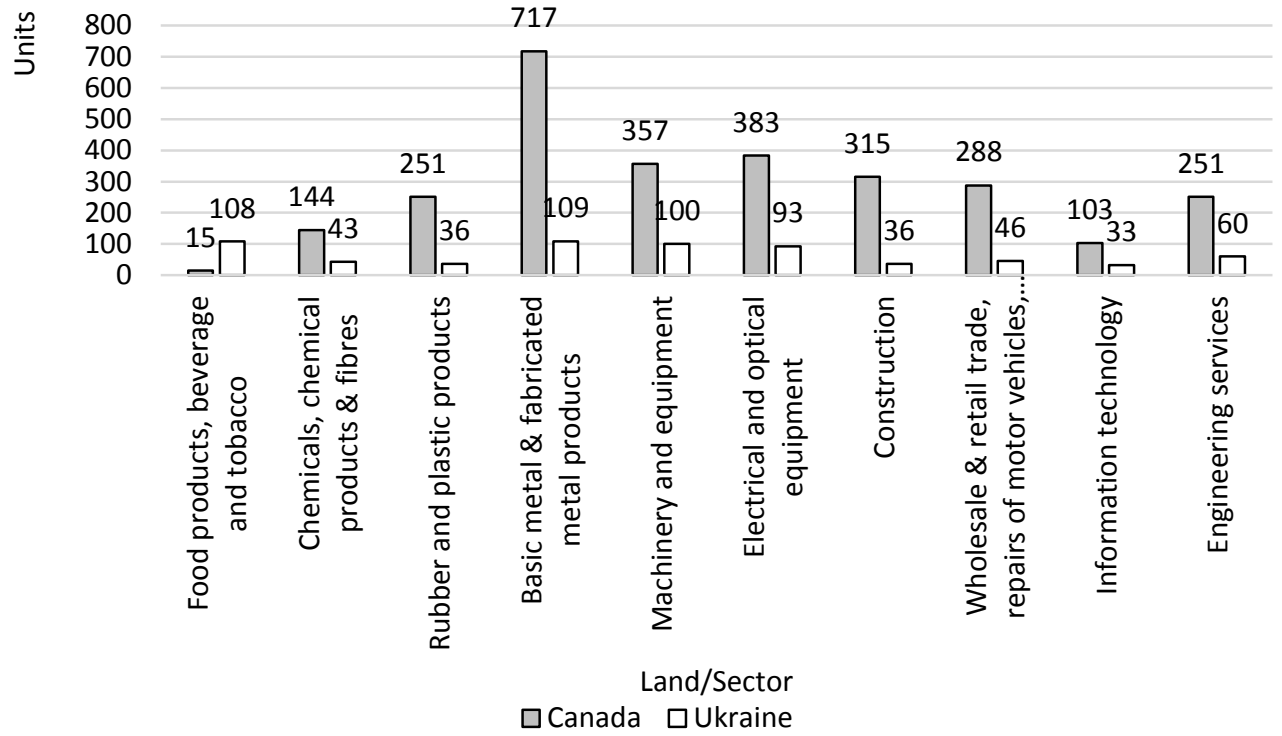

Figure 2. The number of ISO 9001 standards in Canada and Ukraine in the context of the national economy sectors in 2017 (based on the data of the International Organization for Standardization)

Note: * - only those sectors of the economy where the number of standards exceeds 100 units (at least in one country) were selected.

Source: based on the data of the International Organization for Standardization. 
B. V. Derevyanko, O. M. Rieznik, T. V. Shlapko, T. G. Popovych. Fundamentals of a National Standardization System as a Means Confirming the Quality and Innovation of Products: Experience of International Organizations in Ukraine and Canada

Thus, in order to find ways to improve the situation with standardization of activities by domestic business entities and bring it to the level of the leading countries of the world, we will analyze the peculiarities of standardization in Ukraine in more detail. Currently, Ukraine has representatives in nine international, European and regional standardization, metrology and certification organizations. In particular, Ukraine has been a full member of ISO since 1993 and became a member of CEN in 1997 as a correspondent member (the status was specifically for countries that intend to integrate into the EU).

In accordance with the terms of membership, Ukraine can:

1. Creating a strong partnership that will provide certain areas of the economy with a privileged position in the European market.

2. Getting unlimited access to the EN for their adoption (adaptation).

3. Offering national stakeholders the opportunity to become part of the European standardization process and join the leading European industries and companies.

The main advantages Ukraine should promote for the interested parties:

1. Getting direct access to the CEN and CENELEC repositories containing the accumulated expertise of the large CEN and CENELEC network (over 200,000 experts in their industry from 34 countries).

2. An opportunity to promote technical coordination, helping interested individuals enter the market with 600 million consumers and gain additional profit.

3. Becoming an observer in an unlimited number of technical bodies and getting a chance to shape the future EN by opening the «door» of the European single market for itself.

4. Participating in CEN and CENELEC General Assembly meetings as observers. Getting first-hand information on strategic changes in the leading economic bloc.

Conclusions. We propose, based on European and international requirements, as well as requirements for standardization in Canada, to develop national standardization of Ukraine on such grounds:

1. Standards are voluntary and free to use. Unlike laws, standards are not legally binding. They become obligatory if they are mentioned in the contracts and/or legal acts.

2. The task of standardization is to support Ukrainian legislation. The technical regulations should include references to standards that simplify the system and provide an opportunity to speed up and automatically update the legislation when updating the standards.

3. Finding the balance between the requirements that determine essential requirements for human health, environmental safety and product quality, and self-regulation for a business entity. They can freely choose how to comply with the mandatory requirements and automatically benefit from the presumption of conformity for free access to the European market, especially when the products are innovative.

4. Standards are useful and effective in determining liability. Even if the standards are not explicitly mentioned in the contract or the regulatory act, they can be used to resolve legal disputes, especially in cases that concern the liability for product quality. The courts can use standards to decide whether the manufacturer really followed the verified rules and did «due diligence». Thus, standards can provide legal certainty in the application of liability measures.

5 . Standards can be used by a consumer or other interested person to determine whether the product is faultless. Technical standards play a special role in the field of commercial law because interested parties can use them to determine if a product is working properly or not. However, where the use of the standard was not mandatory, non-compliance does not necessarily mean that the product or service is defective. In the end, products can be manufactured properly, even where the standards are not applied, especially when their use is voluntary.

6. Standards must ensure the rights of the parties to the contractor an end user to remove the fault, deliver a fail-safe product or compensate for any damages arising from the lack of guaranteed 
B. V. Derevyanko, O. M. Rieznik, T. V. Shlapko, T. G. Popovych. Fundamentals of a National Standardization System as a Means Confirming the Quality and Innovation of Products: Experience of International Organizations in Ukraine and Canada

characteristics. Standards can be used as protection against damage and can be used to define the subject of liability and distribute damages.

7. Promotion of the value of standardization for business entities. In particular, we talk about the following benefits: improving their products and/or services; attracting new customers; increasing the competitiveness and innovation of products; increasing confidence in business; reducing the number of errors; reducing costs for development and innovation; guaranteeing the compatibility of their products with other components; facilitating the conclusion of contracts and fulfillment of obligations; facilitating access to new markets; increasing the chances of success in the application of standards within the business entity.

The use of standards within the framework of the quality management system allows for the development and promotion of the company, which makes it more efficient and profitable. Standardization promotes innovation. When everyone uses the same principle, based on the latest good idea, which can be implemented more easily, it facilitates the construction of society as safe, reliable, sustainable and profitable. Application of the standard and subsequent decrease in the errors of the process already in its essence will reduce costs. However, unfortunately, these costs can be further reduced to avoid expenses for development and innovation. In such cases, the company analyzes existing examples that have already been tested. Thus, the use of a single standard can have both positive and negative examples. However, in both cases the company saves money. In the first case, standardization facilitates the search and production of an innovative product, and in the second case, on the contrary. However, the company itself has to decide.

Standardization contributes to the development of trade, since, together with lower costs, it eliminates information asymmetry between demand and supply. In an open economy, standardization activities are extremely important for strengthening and trusting business operations in the domestic market or abroad. Standards are the basis for new ideas: they are a constant factor of innovation. The introduction of identifying the basic principles, based on European and international requirements that will allow the construction of the latest national standardization is important and necessary. However, it is also important to implement the mechanism of their application, which should be optimized in the plane of our study.

Author Contributions: conceptualization D. B., R. O.; methodology, S. T., R. O.; formal analysis P. T.; investigation, K. V., F. O.; resources, R. O.; writing - original draft preparation, S. T., R. O.; writing - review and editing, D. B.; visualization, P. T..; project administration D. B., R. O.

\section{References}

Annual Report 2014-15, the Mental Health Commission of Canada (MHCC). URL: https://www. mentalhealthcommission.ca/English/annual-report-2014-2015 (date of treatment: 02.01.2019).

Blind, K., Jungmittag, A., Mangelsdorf, A. (2011). The Economic Benefits of Standardization (An update of the study carried out by DIN in 2000). (23 p). Berlin: DIN German Institute for Standardization.

CAN/CSA-Z1003-13/BNQ 9700-803/2013. URL: http: //shop.csa.ca/en/canada/occupational-health-and-safetymanagement/cancsa-z1003-13bnq-9700-8032013/invt/z10032013 (date of treatment: 02.01.2019).

Corbett, C. J. and Kirsch, D. A. (2001), International Diffusion of ISO 14000 Certification. Production and Operations Management, 10: 327-342. doi:10.1111/j.1937-5956.2001.tb00378.x

Heires, M. (2008). The International Organization for Standardization (ISO). New Political Economy, Volume 13, 2008, Issue 3 P. 357-367. https://doi.org/10.1080/13563460802302693

Husser C.S. et al. (2006) Standardization of Microarray and Pharmacogenomics Data. In: Larson R.S. (eds) Bioinformatics and Drug Discovery. Methods in Molecular Biology, vol 316. DOI https://doi.org/10.1385/1-59259-964-8:111 membership manual. (1946) URL:https://www.iso.org/files/live/sites/isoorg/files/archive/pdf/en/iso_membership_manual.pdf (date of treatment: 02.01.2019).

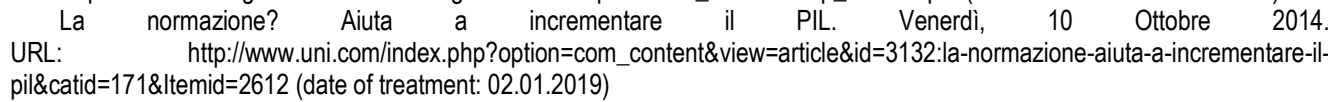


B. V. Derevyanko, O. M. Rieznik, T. V. Shlapko, T. G. Popovych. Fundamentals of a National Standardization System as a Means Confirming the Quality and Innovation of Products: Experience of International Organizations in Ukraine and Canada

Marieke Louis and Coline Ruwet (2017) Representativeness from Within: A Comparison between the ILO and the ISO, Globalizations, 14:4, 535-549, DOI: 10.1080/14747731.2016.1201327

Ram Prasad Vasthare Prabhakar. (2013). A bird's eye view of International Organization for Standardization [ISO]. International Journal of Contemporary Dentistry, Vol 4, No 1. P. 45-49.

Ramune Kasperaviciute (2012). Approach of Higher Education Institutions to ISO 9001 standard: Motives, Issues and Benefits of Implementation. Public Policy and Administration, Vol 11, № 4.

Regulation (EU) No 1025/2012 of the European Parliament and of the Council of 25 October 2012 on European standardization. URL: https://eur-lex.europa.eu/eli/reg/2012/1025/oj (date of treatment: 02.01.2019).

Tennant, A., Grimby, G., Marincek, C., Phillips, S., Ring, H., Biering-Sorensen, F., ... Thonnard, J. (1999). Standardising outcome measurement in physical medicine and rehabilitation across Europe. Eurorehab, (3-4), 178-180.

Zoga, Ira, Pano, Nikollaq. (2016) Effects and Benefits from ISO Certification in Albanian Businesses. European Journal of Multidisciplinary Studies, [S.I.], v. 1, n. 6, p. 131-139, dec. 2016. ISSN 2414-8385. Available at: <http://journals.euser.org/index.php/ejms/article/view/1199>. Date accessed: $28 \quad$ dec. 2018. doi: http://dx.doi.org/10.26417/ejms.v3i1.p131-139.

Ganaba S. (2017). Vid standartyzatsiyi do tvorchosti: implikatsiya idey ta pohlyadiv Kena Robinsona v ukrayins'ku osvitu. Cherkasy University Bulletin: Philosophy. No 1. P. 103-108.

Б. В. Деревянко, д.ю.н., профресор, Донецький юридичний інститут МВС України (Україна);

О. М. Рєзнік, к.ю.н., дочент, Сумський державний університет (Україна);

T. В. Шлапко, к.ю.н., доцент, Сумський державний університет (Україна);

T. Г. Попович, Національна академія правових наук України (Україна).

Засади побудови системи національної стандартизації як засобу підтвердження якості та інноваційності продукції: досвід міжнародних організацій в Україні та Канаді

Статтю присвячено аналізу вимог Міжнародної організації зі стандартизації (International Organization for Standardization), інших міждержавних організацій та національних вимог Канади до стандартизації як засобу підтвердження якості та інноваційності продукиії. На основі проведеного аналізу виявлено особливості та закономірності у правовому регулюванні стандартизації на міжнародному рівні. Значну увагу у статті було присвячено аналізу економіко-правового забезпечення стандартизації у Канаді, де завдяки якісному застосуванню сучасних нормативів стандартизації суб'єктами господарювання було значно підвищено якість продукції на мікроекономічному рівні та основні макроекономічні показники на рівні держави. Підвищення рівня ВВП завдяки застосуванню сучасних стандартів досягають і інші економічно розвинені держави світу. Проведений аналіз із застосуванням методів компаративістики, статистичного та економічного порівняння і моделювання надали можливість ссрормулювати основні засади побудови національної системи стандартизації. Серед них: добровільність та свобода стандартизації; підтримка та оновлення законодавства; збалансування між вимогами, що визначають істотні вимоги щодо здоров'я людини, безпеки для довкілля й якості продукиії, та саморегулюванням для суб'єкта господарювання; корисність та ефрективність стандартів при визначенні відповідальності; допомога споживачу чи іншій зацікавленій особі визначити, чи є продукт «безвідмовним»; забезпечення права сторін у договорі або кінцевого споживача на видалення несправності, доставку безвідмовного продукту або компенсації за будь-які збитки, що виникли через відсутність гарантованих характеристик; популяризація значення стандартизації для суб'єктів господарювання.

Ключові слова: стандартизація, інноваційність, Міжнародна організація зі стандартизації, Канада, якість, суб'єкт господарювання, ефективність.

Manuscript received: 11.01.2019.

(c) The author(s) 2019. This article is published with open access at Sumy State University. 